the development of new machines and providing guidance to manufacturers; and a Mining Research Establishment was set up at Isleworth in 1952. The Safety in Mines Research Establishment of the Ministry of Fuel and Power is still the largest mining research establishment in Britain, and the National Coal Board has inherited very few men experienced. in mining research. In the post-war man-power situation, the Board has found difficulty in recruiting the scientific and technical staff it needs, and this is the main limit on the Board's expansion plans. Mr. Wynn emphasized that production depends on the outcome of a race between increased mechanization and falling man-power in the mines. Two other organizations, however, have also been established which can do much to improve productivity. The Scientific Department has established a Field Investigation Group, analogous to the operational research teams of the Service departments, and the Production Department has set up a Method Study Branch. These establishments are in close touch and will play a big part in reducing man-power requirements.

\section{SOCIAL PROBLEMS OF INDUSTRIAL DEMOCRACY}

$\mathrm{T}$ HE Department of Social Science, University of Liverpool, has published, as Occasional Papers No. 2, "Industrial Democracy : a Revaluation", by W. H. Scott (pp. 40. Liverpool : University Press, 1955 ; 3s. 6d.). This essay is intended to meet the needs of industrialists, trade unionists and others who wish to acquaint themselves rapidly with some of the broad conclusions resulting from systematic research and current thought on this topic. It is limited, however, primarily to problems arising at the factory- or plant-level and is essentially a stocktaking. Industrial democracy is regarded as implying the participation, to a greater or lesser extent, of those who work in industry in determining the conditions of their working lives. The review answers the question, "Is industrial democracy desirable?" with an emphatic affirmative, and Mr. Scott also believes that industrial development has justified our faith in the efficacy of democracy to check the arbitrary use of power.

While an extension of the democratic principle at the formal policy-making level of a firm is important, its application in day-to-day executive leadership is equally vital, and these two processes are interdependent. Mr. Scott makes some constructive comments here, and on the position of the trade unions, which are of especial interest at the moment. $\mathrm{He}$ notes the need to develop "consultative leadership" as part of the administrative routines of a firm at every level, as an essential concomitant to more effective formal procedures at the policymaking levol, pointing out that higher management must take and maintain the initiative in both these respects. He also directs attention to the presupposed attitudes of leadership and administrative ability and to the implications in respect of selection and training for such posts. Similar considerations apply to the trade unions, and if the excessively bureaucratic tendencies of some unions are to be checked, and a balance achieved between the need for a measure of centralized administration and the desirability of developing local initiative and responsibility, then similar criteria must be applied to the selection and training of full-time trade-union officials.

Just as the effective working of any new procedures within the firm calls for a capacity for consultative leadership on the part of managers, so the delegation of greater responsibility to lay-representatives by the unions, which is so essential to industrial democracy, requires appropriate attitudes on the part of officials if it is to be used creatively. Moreover, industry does not exist in vacuo, and Mr. Scott points out that to achieve stable and enduring changes in industry, we must also concern ourselves with developments in other institutions of our society and particularly those which are basic and most formative of personality.

\section{FIBRE MICROSCOPY}

A WELL-ATTENDED symposium and exhibition organized by the Industrial Section of the Royal Microscopical Society was held at the British Pharmaceutical Society in London on November 16, three sessions of papers being given in the lecture theatre, while an exhibition was staged in the hall. Opening the first session of papers, Dr. R. C. Faust discussed the use of the interference microscope in the examination of fibres. The degree of molecular orientation and closeness of molecular packing at different regions of an anisotropic fibre have been studied by means of multiple-beam interference with the conventional microscope and by means of twobeam interference with the Baker interference micro. scope. Mr. D. S. Gowers then described the study, by interferometric methods, of the adhesion between fibres. When an artificial point of contact between a fibre and a quartz plate is examined by incident illumination, Fizeau fringes give a contour map of the fibre surface. The area of contact can be determined by the intensity distribution across the central dark spot. The effect of humidity, temperature and contaminants in the fibre was discussed.

The first two papers in the second session were devoted to the methods of producing replicas for use in the electron microscope. With textile fibres it is the surface that is of main interest, and this may be studied by means of replicas of the fibres, examined under the reflexion electron microscope. The curvature of the fibre presents an added difficulty in obtaining a successful replica, and Dr. J. Dlugosz described the various methods of replication investigated to obtain a successful routine method.

A method of producing solid metal replicas of fibres, for use in the reflexion electron microscope, was then described by D. E. Bradley, who discussed the advantages of this method over that of direct examination, and Dr. K. Little considered the use of the electron microscope in conjunction with other techniques, such as X-ray diffraction, histology and chemical investigations, in the study of fibres in human connective tissues. Each mothod of microscopy has its advantages and its limitations. H. W. Emerton's paper, read by D. H. Page, described how, by using three methods-namely, light microscopy, reflexion electron microscopy and transmission electron microscopy-in the study of natural fibres, a more complete picture can be obtained. By means of a plastic metal replica, the same fibre can be examined by all three methods.

The third session was opened by Dr. A. E. J. Vickers with a short historical survey of the pro. 